\title{
PENGARUH PERMEN JAHE TERHADAP PENURUNAN EMESIS GRAVIDARUM PADA IBU HAMIL TRIMESTER 1 DI WILAYAH PUSKESMAS KALIWUNGU KABUPATEN KENDAL 2016
}

\author{
Ainul Maghfiroh ${ }^{1}$, Lestari Puji Astuti ${ }^{2}$ \\ 1,2Prodi Kebidanan STIKes Karya Husada Semarang \\ Email:tari_rozai@yahoo.co.id
}

\begin{abstract}
Abstrak
Latar Belakang : Mual dan muntah(emesis gravidarum) adalah gejala yang sering muncul pada kehamilan trimester 1.mual biasanya terjadi di pagi hari,tetapi dapat pula terjadi setiap hari dan malam hari, ini terjadi karena relaksasi pada otot-otot pencernaan antara lain peristaltik dilambung sehingga pencernaan makanan oleh lambung menjadi lebih lama dan mudah terjadi peristaltic balik ke esophagus, selain itu juga karena pengaruh dari homon HCG, Di Wilayah Puskesmas Kaliwungu sebanyak 87,9 \% ibu hamil trimester 1 mengalami mual muntah, berbagai macam cara yang dilakukan untuk mengatasi mual muntah salah satunya adalah pemberian permen jahe.. Menurut Dr.Borelli dari University of Naples Frederica di Itali mengatakan bahwa jahe bisa menjadi terapi yang efektif untuk mengatasi mual dan muntah dalam kehamilan. Tujuan : untuk menganalisa pengaruh permen jahe terhadap penurunan emesis gravidarum pada ibu hamil trimester 1 di Wilayah Puskesmas Kaliwungu Kabupaten Kendal. Metode Penelitian : metode penelitiahan ini adalah penelitian pre eksperimen dengan desain static group comparison/ posttest only controlgroup design, menggunakan sampel 38 responden, masing-masing 19 responden untuk kelompok perlakuan dan 19 responden untuk kelompok kontrol. Instrumen yang digunakan untuk mengukur mual muntah adalah lembar observasi. Pengumpulan data dilakukan sendiri oleh peneliti dan data dianalisa secara univariat dan bivariat dengan menggunakan uji test mann whitney. Hasil Penelitian : Hasil penelitian menunjukkan ada pengaruh permen jahe terhadap emesis gravidarum pada ibu hamil trimester 1 dengan nilai $\mathrm{p}$ value $(\mathrm{p}=0,022, \alpha=0,05)$. Kesimpulan : Ada pengaruh permen jahe terhadap penurunan mual muntah pada ibu hamil trimester 1 di Wilayah Puskesmas Kaliwungu Kabupaten Kendal. Diharapkan permen jahe bisa menjadi alternatif pilihan dalam mengatasi emesis gravidarum pada ibu hamil.
\end{abstract}

Kata Kunci: Permen Jahe; emesi; gravidarum Trimester 1

\section{THE EFECT OF GINGER CANDY TO REDUCING EMESIS GRAVIDARUM IN FIRST TRIMESTER OF PREGNANT IN KENDAL KALIWUNGU PUBLIC HEALTH DISTRICT 2016}

\begin{abstract}
Background : Nausea and vomitus(emesis gravidarum) are symptoms that often arises in first trimester pregnancy, ussually occurs in the morning, but can also occurs everyday and night. This occurs due to the relaxztion of the muscles of the digestive include gastric peristaltis so digestion by the stomach longer and forth easily occur peristalsis to esophagus, and also efect from HCG hormone, Kaliwungu Public Health Distric in the region as much as $87,9 \%$ of the first trimester pregnant experience nausea and vomitus. Dr.Borelli dari University of Naples Frederica di Itali say that ginger may be an effective therapi to treat emesis gravidarum. Purpose : to identify the efect ginger candy to reducing emesis gravidarum in first trimester pregnant in Kaliwungu Public Health Kabupaten Kendal. . Method : This reseach used pre eksperiment with static group comparison/ posttest only controlgroup design.each 19 respondent for intervention and control groups. Instrument used to measure emesis gravidarum is cheklist. Collected of the data was carried out by the researcher herself and the collected data was analyzed in univariate, bivariate by using test mann whitney. Result :The result of the research shows that efect ginger candy to reducing emesis gravidarum in first trimester one pregnant $(\mathrm{p}=0,022, \alpha=0,05)$. Conclusion: Ad a ginger candy effect to decrease nausea and vomiting in pregnant women in the first trimester Kaliwungu Regional Health Center Kendal. The expected ginger candy can alternative choice to reduce emesis gravidarum in first trimester pregnant.
\end{abstract}

Key words ; Ginger candy, emesis gravidarum trimester 1 


\section{Pendahuluan}

Kehamilan merupakan suatu proses reproduksi yang perlu perawatan khusus agar berlangsung dengan baik.(Walyani,2015:1). Dengan adanya kehamilan maka akan terjadi perubahan pada ibu baik fisiologis maupun psikologis, perubahan tersebut sebagian besar adalah karena pengaruh hormone yaitu peningkatan hormone progesterone dan esterogen, Peningkatan hormone tersebut maka akan muncul berbagai macam ketidaknyamanan secara fisiologis pada ibu hamil trimester 1 misalnya mual muntah (Walyani,2014: 77).

Beberapapeneliti mengungkapkan keterkaitan hormone HCG (Hormone Corionic Gonadotropin) dengan gejala mual muntah yang kerap dialami oleh wanita hamil, yang biasanya membaik setelah trimester pertama. Muntah terjadi ketika pusat muntah di medulla atau zona pemicu kemoreseptor yang terletak di dinding lateral ventrikel ke empat terstimulasi. Pada sebagian wanita hamil gejala tersebut lebih sering muncul saat bangun tidur sehingga kerap di sebut dengan morning sicknes, akan tetapi pada sebagian yang lain gejala mual muntah terus berlanjut sepanjang hari.(Holmes, 2011: 43)

Penanganan farmakologi seperti pemberian obat antiemetik dan anti histamine, Penanganan non farmakologi meliputi terapi nutrisi, penggunaan akupuntur dan penggunaan pengobatan herbaTerapi penggunaan tanaman herba misalnya dengan jahe.(Tiran, 2008: 57)

Menurut German federal Health Agency jahe efektif untuk mengobati gangguan pencernaan karena jahe mengandung 2 enzim pencernaan penting dalam membantu tubuh mencerna dan menyerap makanan, pertama lipase yang berfungsi menyerap lemak dan kedua protease yang berfungsi memecah protein.(Setyawan, 2015: 26). Dr.Borelli dari University of Naples Frederica di Itali mengatakan bahwa jahe bisa menjadi terapi yang efektif untuk mengatasi mual dan muntah-muntah dalam kehamilan (Geniofam, 2010: 42). Terdapat sedikit bukti bahwa vitamin B6 dapat membantu mengurangi keparahan mual (Baston, 2012: 43)

Wilayah Kerja Puskesmas Kaliwungu terdiri dari 9 Desa dengan 12 Bidan Desa, untuk mendapatkan data awal terkait hal tersebut peneliti melakukan survey data ke Wilayah Puskesmas tersebutdi dapatkan hasil bahwa data kunjungan ibu hamil trimester 1 pada tahun 2015 sebanyak 379 orangdan yang mengalami mual muntah sebanyak 332 orang yaitu $87,59 \%$,. Dari hasil tersebut bahwa sebagian besar ibu hamil trimester 1 mengalami emesis gravidarum.

Berdasarkan studi pendahuluan yang dilakukan oleh peneliti dengan wawancara kepada $10 \mathrm{ibu}$ hamil trimester 1 yang mengalami mual muntah 5 diantaranya mengatakan 
sudah mendapatkan obat mual muntah namun tetap merasakan mual, 3 orang diantaranya menyatakan mendapat perbaikan setelah meminum obat untuk mual tersebut, 2 lainnya mendapat perbaikan dengan beristirahat dan mengatasinya dengan minum air putih hangat dan tidak meminum obat walaupun sudah mendapat obat.

Emesis gravidarum memang bukan gejala yang dapat membahayakan kehamilan karena merupakan perubahan fisiologi/ketidaknyamanan kehamilan trimester 1, tapi mual dan muntah bisa menjadi kecemasan tersendiri bagi ibu hamil bila tidak diatasi dengan baik.

Rumusan masalah yaitu adakah pengaruh permen jahe terhadap penurunan emesis gravidarum pada ibu hamil trimester 1

Tujuan Penelitian untuk menganalisis pengaruh permen jahe terhadap penurunan emesis gravidarum pada ibu hamil trimester 1 di wilayah Puskesmas Kaliwungu Kabupaten Kendal tahun 2016.

\section{Tinjauan Teoritis}

1 Kehamilan trimester pertama adalah kehamilan antara umur $0-12$ minggu (Hani, 2011:70)

2 Mual dan muntah(emesis gravidarum) adalah gejala yang sering muncul pada kehamilan trimester 1.mual biasanya terjadi di pagi hari,tetapi dapat pula terjadi setiap hari dan malam hari (Wiknjosastro, 2007: 275)

3 Faktor yang dapat mempengaruhi penurunan emesis gravidarum:

a. Farmakologi: Anti emetic, Anti histamine

b. Non farmakologi: Tirah baring, Terapi nutrisi, Akupuntur, Terapi psikologi,

Hipnoterapi, Dukungan keluarga, Terapi herba(Jahe, Pepermin, kamomile),

Relaksasi, Aromatherapi, Yoga

4 Jahe

Jahe dalam bentuk tablet atau teh dapat mengurangi mual (Medforth dkk,2011:80). Jahe dapat mencegah mual karena mampu menjadi penghalang serotonin, sebuah senyawa kimia yang dapat menyebabkan perut berkontraksi, sehingga timbul rasa mual.(Ramadhan, 2013:94). Jahe dapat diminum 3x sehari pagi siang malam untuk mengurangi mual pada kehamilan.(Dalimartha dan Adrian, 2013: 45). 


\section{Metode Penelitian}

Jenis penelitian ini adalah kuantitatif eksperimen dengan Desain penelitian yaitu static group comparison/ posttest only controlgroup design yaitu merupakan rancangan pre eksperimental design dengan menambah kelompok kontrol, yaitu setelah perlakuan dilakukan pengamatan pada kelompok perlakuan dan pada kelompok kontrol dilakukan pengamatan saja (Hidayat,2007: 60 )

Kelompok perlakuan : X $\quad$ O1

Kelompok Kontrol : $\quad-\quad \mathrm{O} 2$

Keterangan :

$X$ : Pemberian permen jahe 3x sehari selama 6 hari

O1: Penurunan emesis gravidarum pada ibu hamil trimester 1 pada kelompok perlakuan,setelah pemberianpermen jahe

$\mathrm{O} 2$ :Penurunan emesis gravidarum pada ibu hamil trimester 1 pada kelompok kontrol

Populasi dalam penelitian ini adalah semua ibu hamil trimester 1 yang mengalami emesis gravidarum Wilayah Puskesmas Kaliwungu. Sampel penelitian sebanyak 38 responden.Teknik pengambilan sampel dalam penelitian ini menggunakan purposive sampling. Penelitian ini dilakukan pada bulan September 2016. Analisa data meliputi analisa univariatdilakukan terhadap tiap variabel dari hasil penelitian dan analisa bivariat dengan terlebih dahulu Melakukan uji normalitas data terlebih dahulu dengan Shapiro wilk karena sampel $<50$, dikatakan normal bila $\mathrm{p}$ value $>0,05$. Bila data berdistribusi normal( $\mathrm{p}$ value $>$ 0,05) maka menggunakan uji T-independent. Bila data berdistribusi tidak normal ( $\mathrm{p}$ value $<$ $0,05)$ maka menggunakan uji mann whitney.

\section{Hasil Penelitian}

1. Deskripsi pada kelompok perlakuan

Tabel 1 Distribusi Frekuensi pengaruh permen jahe pada kelompok perlakuan

\begin{tabular}{lcc}
\hline Kategori & Frekuensi & Persentase (\%) \\
\hline Mual muntah & 4 & 21,1 \\
Tidak mual muntah & 15 & 78,9 \\
\hline \multicolumn{1}{c}{ Total } & 19 & 100,0 \\
\hline
\end{tabular}

Berdasarkan data tabel 1 menunjukkan bahwa 4 responden $(21,1 \%)$, masih mengalami mual muntah dan 15 responden $(78,9 \%)$ tidak mengalami mual muntah. 
2. Deskripsi pada kelompok kontrol

Tabel 2 Distribusi Frekuensi pengaruh permen jahe pada kelopok kontrol

\begin{tabular}{lcc}
\hline \multicolumn{1}{c}{ Kategori } & Frekuensi & Persentase (\%) \\
\hline Mual muntah & 11 & 57,9 \\
Tidak mual muntah & 8 & 42,1 \\
\hline Total & 47 & 100,0 \\
\hline
\end{tabular}

Berdasarkan data tabel 2 menunjukkan bahwa responden yang mengalami mual muntah yaitu 11 responden $(57,9 \%)$ dan yang tidak mengalami mual muntah sebanyak 8 responden $(42,1 \%)$.

3. Pengaruh permen jahe terhadap penurunan emesis gravidarum pada ibu hamil trimester 1

Tabel 3 Pengaruh permen jahe terhadap penurunan emesis gravidarum pada ibu hamil trimester 1

\begin{tabular}{|c|c|c|c|c|c|c|c|}
\hline \multirow{3}{*}{ Ibu Hamil Trimester 1} & \multicolumn{6}{|c|}{ Frekuensi } & \multirow[t]{3}{*}{$\mathrm{P}$ value } \\
\hline & \multicolumn{2}{|c|}{$\begin{array}{c}\text { Perlakuan } \\
\mathrm{N}=19\end{array}$} & \multicolumn{2}{|c|}{$\begin{array}{c}\text { Kontrol } \\
\mathrm{N}=19\end{array}$} & \multicolumn{2}{|c|}{ Total } & \\
\hline & $\mathrm{F}$ & $\%$ & $\mathrm{~F}$ & $\%$ & $\mathrm{~F}$ & $\%$ & \\
\hline Mual muntah & 4 & 21,1 & 11 & 57,9 & 15 & 39,4 & 0,022 \\
\hline Tidak mual muntah & 15 & 78,9 & 8 & 42,1 & 23 & 60,5 & \\
\hline Total & 19 & 100 & 19 & 100 & 38 & 100 & \\
\hline
\end{tabular}

Berdasarkan Tabel 3 Hasil uji statistik untuk mengetahui pengaruh permen jahe terhadap penurunan emesis gravidarum pada ibu hamil trimester 1 yaitu dengan menggunakan uji non parametrik 2 sampel tidak berpasangan (mann whitney) diketahui bahwa nilai $\mathrm{p}$ value adalah 0,022 . Sehingga dinyatakan hipotesa Ho ditolak dan Ha diterima, artinya ada pengaruh permen jahe terhadap penurunan emesis gravidarum pada ibu hamil trimester 1

\section{Pembahasan}

1. Deskripsi Kelompok perlakuan

Hasil penelitian menunjukkan bahwa setelah pemberian permen jahe yaitu di berikannya permen jahe selama 6 hari dengan dosis 3 kali sehari di dapatkan hasil bahwa sebagian besar responden yaitu sebanyak 78,9 \% mengalami perbaikan atau tidak mengalami mual muntah lagi.

Permen jahe merupakan permen yang berisi ekstrak jahe, jahe diketahui sebagai tanaman rempah dan obat yang sudah lama di kenal masyarakat yang mempunyai sejuta 
manfaat salah satunya adalah dalam mengurangi mual muntah, jahe bersifat menghangatkan, dimana pada ibu yang mengalami mual muntah yang di sebabkan oleh banyak hal salah satunya yaitu gerakan peristaltik usus yang lambat, dengan adanya sifat hangat pada jahe sehingga dapat mengurangi keluhan tersebut. Jahe juga mempunyai aroma yang khas yang berasal dari minyak atsiri sehingga dapat pula sebagai aromaterapi pilihan untuk mengurangi mual, penggunaaan jahe bersamaan dengan vitamin B6 sangat efektif dalam mengurangi mual muntah

2. Diskripsi Kelompok kontrol

Pada kelompok kontrol yaitu kelompok yang tidak mendapatkan tambahan permen jahe sebagai pengurangan mual muntah pada ibu hamil trimester 1 dimana kelompok ini hanya mendapatkan vitamin B6 saja dengan dosis yang sama yaitu di berikan 3 kali sehari selama 6 hari sesuai dengan Tabel 4.2 di dapatkan hasil bahwa 42, $1 \%$ mual muntah menghilang dan 57,9 \% masih mengalami mual muntah, dalam hal ini berarti sebagian besar ibu hamil masih mengalami mual muntah.

Vitamin B6 atau biasa di sebut piridoksin adalah juga termasuk salah satu pengobatan alternatif dalam pengurangan mual muntah namun penggunaannya setelah di bandingkan dengan kelompok perlakuan yang mendapatkan permen jahe bahawa hanya 42, $1 \%$ yang mendapat perbaikan. Berarti sebagian besar masih mengalami mual muntah

Dalam (Baston, 2012: 12) menyatakan terdapat sedikit bukti bahwa vitamin B6 dapat membantu mengurangi keparahan mual yang dialami oleh ibu hamil. Stephen raymond, spesialis obstetri dan ginekologi di Rumah Sakit Royal Tasmania mengatakan bahwa vitamin B6 dapat mengurangi rasa mual muntah pada sekitar 20 persen pada wanita hamil (Anwar, 2016)

Mual muntah selain karena di sebabkan oleh hormonal, bisa juga terjadi karena faktor lain yaitu karena keadaan psikologi yang mempengaruhi, bila karena faktor psikologi tentu dengan pemberian antimual tidak akan terlalu bermanfaat. Menurut beberapa penelitian di duga dengan konsumsi vitamin B6 akan membantu mengurangi rasa mual muntah pada beberapa wanita, tetapi tidak pada semua wanita. Dan para ahli sendiri masih belum mengetahui dengan pasti bagaimana vitamin B6 berpengaruh untuk mengatasi rasa mual ini.(Suririnah,2006).

3. Pengaruh permen jahe terhadap penurunan emesis gravidarum pada ibu hamil trimester 1

Berdasarkan Penelitian yang telah dilakukan di Wilayah Puskesmas Kaliwungu Kabupaten Kendal kepada 38 responden yang terbagi menjadi dua kelompok yaitu 19 responden untuk kelompok perlakuan dan 19 responden untuk kelompok kontrol, di 
dapatkan hasil bahwa pada kelompok perlakuan yang di lakukan kepada 19 responden setelah di berikan permen jahe selama 6 hari dengan dosis 3 kali sehari di dapatkan hasil bahwa sebanyak 15 responden $(78,59 \%)$ tidak mengalami mual muntah, dan hanya 21,11 $\%$ masih mengalami, sedangkan pada kelompok kontrol yang tidak memperoleh tambahan permen jahe hanya 8 responden saja yang mengalami perbaikan $(42,11 \%)$, dan sisanya $57,9 \%$ masih mengalami mual muntah.

Hasil uji statistik untuk mengetahui pengaruh permen jahe terhadap penurunan emesis gravidarum pada ibu hamil trimester 1 yaitu dengan menggunakan uji non parametrik 2 sampel tidak berpasangan (mann whitney) didapatkan bahwa nilai p value adalah 0,022. Dimana berarti $\mathrm{P}$ value $<0,05$, Sehingga dinyatakan hipotesa Ho ditolak dan Ha diterima, yang artinya ada pengaruh permen jahe terhadap penurunan emesis gravidarum pada ibu hamil trimester 1.

Menurut German federal Health Agency jahe efektif untuk mengobati gangguan pencernaan karena jahe mengandung 2 enzim pencernaan penting dalam membantu tubuh mencerna dan menyerap makanan, pertama lipase yang berfungsi menyerap lemak dan kedua protease yang berfungsi memecah protein.(Setyawan, 2015: 26). Dengan adanya kedua enzim tersebut tentu makanan yang masuk ke lambung lebih mudah tercerna dan terserap oleh tubuh sehingga makanan tidak tertahan di lambung yang dapat memicu terjadinya perasaan eneg yang pada akhirnya perasaan eneg tersebut akan menimbulkan perasaan panas dilambung dan merangsang mual ataupun muntah. Dalam (Budhwaar: 2006) juga di jelaskan bahwa salah satu fungsi farmakologis jahe adalah antiemetik (anti muntah)

Dalam hal ini peneliti menggunakan permen jahe kemasan yang sudah jadi yang diberikan selama 6 hari dengan dosis 3 kali sehari pada ibu hamil yang mengalami emesis gravidarum, diharapkan selama 6 hari mengkonsumsi permen jahe, mual muntah yang dialami oleh ibu bisa berkurang. Pemberian dosis 3 kali sehari didasarkan pada buku (Dalimartha dan Adrian, 2013: 45) yaitu Jahe dapat diminum 3x sehari pagi siang malam untuk mengurangi mual pada kehamilan.

Jahe dapat mencegah mual karena mampu menjadi penghalang serotonin, sebuah senyawa kimia yang dapat menyebabkan perut berkontraksi, sehingga timbul rasa mual, merupakan bahan yang mampu mengeluarkan gas dari dalam perut, hal ini akan meredakan perut kembung, juga merupakanstimulan aromatik yang kuat, disamping dapat mengendalikan muntah dengan meningkatkan gerakan peristaltik usus. Sekitar 6 senyawa di dalam jahe telah terbukti memiliki aktivitas antiemetik (anti muntah) yang manjur. Kerja 
senyawa-senyawa tersebut lebih mengarah pada dinding lambung dari pada system saraf pusat. kandungan minyak atsiri dan zat zingeron bisa menghilangkan mual pada ibu hamil dan membuat perut menjadi nyaman dan hangat.

Permen jahe bisa menjadi salah satu alternatif dalam mengatasi mual muntah pada ibu hamil trimester 1 , seperti di jelaskan diatas bahwa khasiat jahe memang terbukti memiliki aktivitas antiemetik yang manjur, jahe mempunyai sifat yang ringan, dan tidak akan menimbulkan efek samping yang dapat membahayakan kehamilan baik bagi ibu maupun bayi, jahe bisa di konsumsi dalam bentuk apapun misalnya permen, minuman, manisan, atau tablet, jahe juga bisa di konsumsi utuh, ibu hamil terkadang malas atau enggan meminum obat, permen jahe bisa menjadi salah satu alternatif dalam mengatasi mual muntah, rasa yang hangat di perut memberkan kenyamanan tersendiri bagi ibu. Peneliti dalam hal ini menggunakan permen kemasan yang sudah jadi sebagai media pemberian ekstrak jahe karena permen mempunyai sifat yang mudah untuk di terima, mudah dicari dan bisa di bawa kemana saja, ibu tidak perlu repot menggunakan air dan gelas seperti halnya bila di berikan lewat minuman.

Hasil penelitian ini sesuai dengan penelitian yang dilakukan oleh Cathur Dian (2014) bahwa jahe lebih efektif dalam mengurangi mual dibandingkan dengan pepermint dan penelitian oleh Chopra (2006 )yang menemukan tiga dari empat wanita hamil merasakan mual berkurang berkat jahe, tanpa efek samping yang membahayakan.

Mual muntah atau emesis gravidarum memang bukanlah suatu hal yang bersifat patologis dalam kehamilan namun kehadirannya dapat menjadi suatu ketidaknyamanan tersendiri bagi ibu hamil trimester 1, dan mual muntah yang tidak di atasi dengan baik dapat mengarah pada hiperemesis gravidarum, atau mual muntah yang terjadi secara berlebihan, Secara fisiologis, rasa mual terjadi akibat kadar estrogen yang meningkat dalam darah sehingga mempengaruhi sistem pencernaan.Tetapi mual dan muntah yang terjadi terus menerus dapat mengakibatkan dehidrasi, hiponatremia, whipokloremia, serta penurunan klorida urine. Untuk itu peneliti menguji cobakan pada permen jahe sebagai salah satu alternatif untuk mengurangi emesis gravidarum pada ibu hamil trimester 1

\section{Kesimpulan}

1. Hasil penelitian menunjukkan bahwa pada kelompok perlakuan sebagian besar tidak mengalami mual muntah

2. Hasil penelitian menunjukkan bahwa pada kelompok kontrol sebagian besar masih mengalami mual muntah. 
3. Ada pengaruh permen jahe terhadap penurunan mual muntah pada ibu hamil trimester 1 di Wilayah Puskesmas Kaliwungu Kabupaten Kendal

\section{Saran}

1. Bagi puskesmas, Diharapkan penelitian ini bisa menambah referensi dalam mengatasi mual muntah

2. Bagi Institusi Pendidikan, Diharapkan hasil ini dapat menjadi referensi bagi para mahasiswa tentang penelitian

3. Bagi ibu hamil, Ibu hamil yang mengalami mual- muntahmaupun keluarga dapat menerapkanpengobatan herbal yang tepat untuk mengobatigejala mual muntah salah satunya mengkonsumsiekstrak jahe

\section{Daftar Referensi}

Baston, hellen dan Jennifer hall. 2012. Midwifery Essentials Antenatal. Jakarta: EGC

Dalimartha dan Adrian. 2013. Ramuan Herbal Tumpas Penyakit. Jakarta: Penebar Swadaya

Fajar, Ibnu dkk. 2009. Statistika Untuk Praktisi Kesehatan. Yogyakarta: Graha Ilmu

GenioFam.2010. 99 Tips Mempersiapkan Dan Menjaga Kehamilan. Yogyakarta : Gravina Mediacipta

Hani, Ummi dkk.2011. Asuhan Kebidanan pada Kehamilan Fisiologis. Jakarta : Salemba Medika

Hidayat, Aziz A.2011. Metode Penelitian Kebidanan dan Teknik Analisa Data. Jakarta: Salemba Medika

Marhari, Yunita O. 2015. Herbal Sehat dan Aman Untuk Ibu Hamil Dan Menyusui. Klaten : CV Sahabat.

Marmi. 2014. Asuhan Kebidanan Pada Masa Antenatal. Yogyakarta : Pustaka Pelajar

Napitupulu, Miranda D. 2010. Budidaya Jahe. Jakarta: Rawansah

Notoatmodjo, S. 2011. Metodologi Penelitian Kesehatan. Jakarta : Rineka Cipta

Ramadhan, J A.2013. Aneka Manfaat Ampuh Rimpang Jahe Untuk Pengobatan. Yogyakarta: Diandra pustaka Medika

Sulistyawati, Ari. 2009. Asuhan Kebidanan Pada Masa Kehamilan. Jakarta: Salemba Medika Setyaningrum, Dwi Hesti. 2015. Jahe. Jakarta : Penebar Swadaya

Suririnah,dr. 2006. Vitamin B6 untuk mul muntah hamil muda?.www.infoibu.com diakses tanggal 20 Juli 2016 
Tiran, Denise. 2007. Mengatasi Mual dan Gangguan Lain Selama Kehamilan. Jakarta : Diglosia.

.2008. Mual Muntah Kehamilan, Jakarta : EGC .

Walyani, Siwi E. 2015. Asuhan kebidanan Pada Kehamilan. Yogyakarta : Pustaka Barupress

Wiknjosastro. 2007. Ilmu Kebidanan. Jakarta :Yayasan Bina Pustaka Sarwono Prawiroharjo 